\title{
Methods of assessing the paying capacity of an agricultural firm considering the operating mode
}

\author{
Andrey Brodunov ${ }^{1,}{ }^{*}$, Natalya Bushueva ${ }^{1}$, Andrey Pizhurin ${ }^{2}$, and Ekaterina Berezina ${ }^{3}$ \\ ${ }^{1}$ Moscow Witte University, 12, 2nd Kozhukhovsky pas., Bldg. 1, Moscow 115432, Russia \\ ${ }^{2}$ Moscow State University of Civil Engineering, 26 Yaroslavskoye Shosse, 109377, Moscow, Russia \\ ${ }^{3}$ Vyatka State University, Moskovskaya str., 36, Kirov, 610000, Russia
}

\begin{abstract}
In Economic operators Finance theory they have described many models and approaches to assessing the criteria of a firm's ability to be liable for its debts to the contractors. Despite the fact that the issue of submitting to payment discipline is extremely important nowadays, in practice these approaches and models are used in checking the potential paying capacity either of the contractor or of one's own firm. The main issue consists in the fact that many rather dogmatic criteria used in the process actually do not lead to accurate results, thus resulting in quite the opposite conclusions due to their abstractedness, as well as to 'uncertainty' of the input data. The aim of the paper is to show the ways of calculating one of the key and the most currently used criterion of paying capacity the absolute liquidity ratio. The paper considers advantages and disadvantages of the already existing approaches, analyzes the results of a negligent approach to payment capacity analysis by the example of calculating the criterion in question. The theoretical background is offered for practical approbation of the viability of the method offered in the paper. The practical part offers a set of successive calculations, shows the algorithm of the calculations according to the method in question.
\end{abstract}

\section{Introduction}

The Analysis of paying capacity is an important part of assessing the finance state of a firm. Paying capacity of a firm consists in sufficiency of the finance at the command for timely fulfilling pecuniary obligations either by law or by the contract. What appears to be very important for assessing paying capacity is any obligations within the time limit. A set of factors can decrease the paying capacity, these factors to some degree reflect the efficiency of finance management, such as: financial misconduct, a low level of net cash flow, inefficient stocks management, a high degree of financial dependence on credit grantors, etc. [6]

The most common approach to assessing paying capacity is broadly used and it is a formalized part of the finance analysis on the basis of the accounting data.

\footnotetext{
*Corresponding author: abrodunov@muiv.ru
} 
In general this is the approach to calculating the data given in percentage; the data allow comparing the indexes of the accounts of the finance results and the indexes of the balance sheet accounts.

Still most of analysts treat the conception of liquidity as the organization's having current assets sufficient for fulfillment of current obligations [4]. $[4,1]$ :

In this case to assess the paying capacity one should calculate the main ratios, such as

- current liquidity ratio;

- quick liquidity ratio;

- absolute liquidity ratio.

\section{Materials and methods}

Liquidity ratios show the share of obligations which a firm can fulfill by realizing its assets at the market price within the exposure period typical for assets in question.

In a strict sense, of the whole set of criteria used at liquidity calculation, just the absolute liquidity ratio can serve as an indicator of paying capacity [2].

And the absolute liquidity ratio is calculated according to the standard formula:

$$
R a b r=\frac{\mathrm{A} 1}{P 1+P 2}
$$

Evidently, this criterion points at the potential payment of short-term debts as a result of using just absolutely liquid assets.

The analytical results of the calculation are most often "standardized" relating to one of several criteria:

- A generally accepted standardized normative criterion used as a dogma in academic books (for example, the ratio not less than 0.2 is considered as a norm) [3];

- An average ratio for all the firma of one branch of industry [7].

The first way of interpreting the ratio is simple, which is the advantage of it. But there is an issue that the "norm" often does not reflect the real state of functioning of different firms in different spheres; many firms have been functioning quite successfully for years without complying with the generally accepted "norm".

The second way can be applied only to the organizations with similar, compatible elements of financing structure, approaches to dept management, relations with suppliers and clients, and other elements of the business-model.

It is well-known that not all the firms belonging to the same sphere of industry could be compatible in the above-mentioned features. Thus, in practice this way is not always easy applicable.

The aim of the paper is to consider and to try the method of calculating the norm of the absolute liquidity ratio for a definite firm, taking into account its individual and peculiar operating mode.

This way of calculating is the most complicated and the most routine, as compared with the above mentioned ones. Still it can spare the analyst's effort of looking for some analogous firms or making an improper conclusion as a result of using unreasonable "norm" criteria. Besides, calculating the "norm" for a definite firm allows taking into account its specifics and its real need in monetary assets.

The description of the method is as follows. It is offered that the calculation has several steps:

- Calculating the average daily flow.

- Calculating the level of coverage of current payments.

- Finding out any possible cash gaps. 
- Calculating the minimum spare money.

- Calculating the adapted statutory value of the absolute liquidity ratio.

Thus at the first stage it is necessary to calculate amount of money assets necessary to the firm for its successful operating. Thus the money outlays for the period of time could be calculated according to the formula:

$$
M o p=C g s-\mathrm{A}+S c+A e+T+\Delta S
$$

in which:

Mop - the money outlays for the period of time;

$\mathrm{Cgs}$ - the cost of goods sold;

A - maintenance;

Sc - selling costs;

Ae - administration expenses;

$\mathrm{T}$ - the taxes paid;

$\Delta \mathrm{S}$ - stock changes for the period of time.

It is necessary to mention that in the formula the amount of taxes paid contains only the taxes not included in the cost of goods sold. As for stock changes, only the changes mentioned in the balance-sheet items "Production stocks", "Goods in process", and "Finished products" are taken into account.

According to the above-mentioned formula, one can calculate the money resources needed by the firm for the whole year. To calculate the average daily flow one is to divide the result by the number of calendar days. The formula is as follows:

$$
a v M o p=\frac{M o p}{360}
$$

in which:

avMor - the average daily flow of the firm;

Mop - the money outlays for the period of time.

To calculate the coverage level of the current payments one should divide the average balance of the money assets by the average daily flow:

$$
C P C=\frac{A v M O Y}{a v M o r}
$$

in which:

$\mathrm{CPC}$ - the coverage of the current payments;

AvMOY - the average money outlay per year;

avMop - the average daily flow of the firm.

The calculating shows for how many days the current stock of spare money will be enough for current operations funding.

For assessing paying capacity of the firm on the basis of the criterion calculated it is necessary to set the difference between the average pay period of current supplier's accounts and the average pay period of customers' accounts. It enables one to find out any possible cash gaps. The difference in question could be stated for a certain firm on with basis of an expert evaluation using the data of the payment schedule. The specific features of accounts of the time period in question are also taken into account. For example, the necessity of advance payments and making discounts, both on the side of the firm and on the side of its suppliers.

The issue consists in the fact that the published accounts of the firm do not contain any payment schedule. So in calculating the rough length of cash gaps one can use the difference between the receivables turnover and payables turnover. Thus the formula is the following: 


$$
C G=|P r t-P p t|
$$

in which:

$\mathrm{CG}$ - cash gap;

Prt - the period of receivables turnover [6];

$\mathrm{Ppt}$ - the period of payables turnover [6].

Then it is possible to calculate the average "safe" cash balance:

$$
N c b=C G * A v M o p .
$$

in which:

$\mathrm{Ncb}$ - the necessary cash balance;

$\mathrm{CG}$ - cash gap;

avMop - the average daily flow of the firm

It allows calculating the amount of cash resources necessary within the period of a time cash gap, i. e. between the date of payment to the suppliers and the date of getting cash from the debtors.

This criterion could be used in calculating the adapted statutory value of the absolute liquidity ratio, which actually is the last step in calculating.

The following formula is used here:

$$
\operatorname{Ralr}_{\mathrm{H}}=\frac{N c b}{P 1+P 2}
$$

in which:

RalrH- the statutory value of the absolute liquidity ratio

$\mathrm{Ncb}$ - the necessary cash balance;

P1 - credit indebtedness;

P2 - short-term borrowed assets and other short-term liabilities.

\section{Results}

For the practical part of the research presented in the paper the standard financial accounting of an enterprise operating with the sphere of heavy machine building (further the firm).

At the first stage the amount of finance of dayly necessity to the firm is calculated. To do this the formulae (2) and (3) are used. Calculation results are given in Table 1.

Table 1. Calculating the average daily flow, thousand roubles.

\begin{tabular}{|l|c|c|c|}
\hline \multicolumn{1}{|c|}{ Criterion } & $\mathbf{2 0 1 8}$ & $\mathbf{2 0 1 9}$ & $\mathbf{2 0 2 0}$ \\
\hline Costs price & 4438398 & 6329533 & 5461582 \\
\hline Maintenance & 80052 & 103265 & 116055 \\
\hline Selling costs & 196586 & 273822 & 350372 \\
\hline Administration expenses & 346301 & 405079 & 507526 \\
\hline Taxes & 25203 & -82878 & 42577 \\
\hline Stock changes & 161042 & 404310 & -109407 \\
\hline The average daily flow & $\mathbf{1 3 9 9 2}$ & $\mathbf{2 0 ~ 5 3 4}$ & $\mathbf{1 6 8 1 0}$ \\
\hline
\end{tabular}

The table shows that in 2019 the need in finance was the biggest, at that time the amount of produced goods was growing. Most probably, the next year cost reduction is connected with product shipment in 2019. It caused stock decrease and increase of selling costs in shipment and equipment installation. 
The next step of the research consists in calculating the level of coverage of current payments. The necessary data are presented in Figure 1.

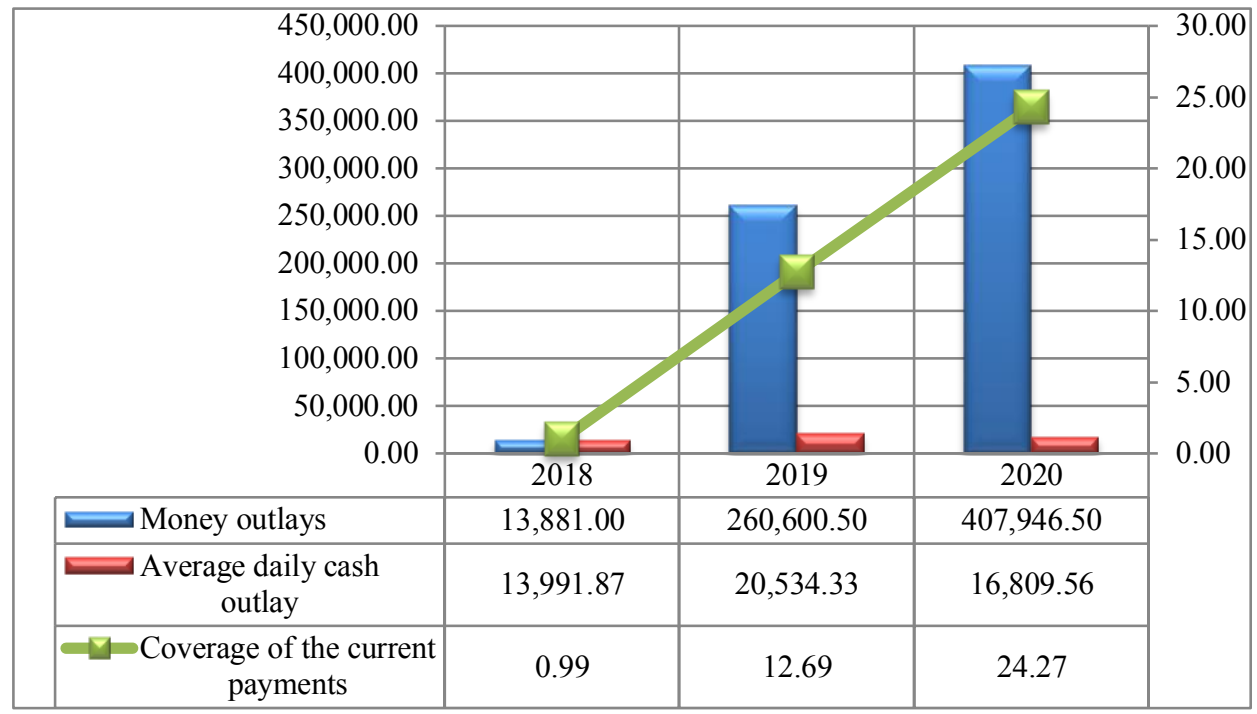

*the index "Cash Assets" is used in calculating as follows from line 1250 of the Balance-sheet

* The level of fulfilling the current payments is calculated according to the formula (4)

Fig. 1. The level of fulfilling the current payments.

Picture 1 shows that money assets of the firm account also increase, and then the level of coverage of current payments also increases during the research period of time. In 2018 the firm did not have enough finance to cover the expenses of one day, and in 2020 it could cover the expenses of 24 days. It is a positive tendency, as the firm should have assets for autonomous work independent of external receipts.

Then the minimal cash asset necessary for the firm within the period of payments to creditors and payments of the debtors is to be calculated. The visual image of it is presented in Fig.2.

According to the calculations made the necessary cash assets for the firm grow within the whole period of time under research. It is not connected with the general increase of money demand, as in 2020 this demand decreased almost by 4 million rubles, while the necessary cash assets go on growing. The reason of it consists in the fact that debit indebtedness is increasing, so the number of days for financing in any way is also growing. At the same time payables turnover is decreasing in days. It means that the firm is good at servicing its debts to its creditors.

The picture shows that a part of the most urgent obligations, which are to be paid off by the spare money from the payment account, increases and in 2020 this part reaches $86 \%$. Thus, in conditions of growing cash gaps, the firm should freeze more and more money assets on its accounts, otherwise it would not be able to finance its manufacturing cycle.

If one compares of the result of the calculations made with the result of those according to the standard formula (1) of the absolute liquidity ratio one could notice a considerable disparity. It could lead to wrong conclusions and decisions (Fig. 4). 


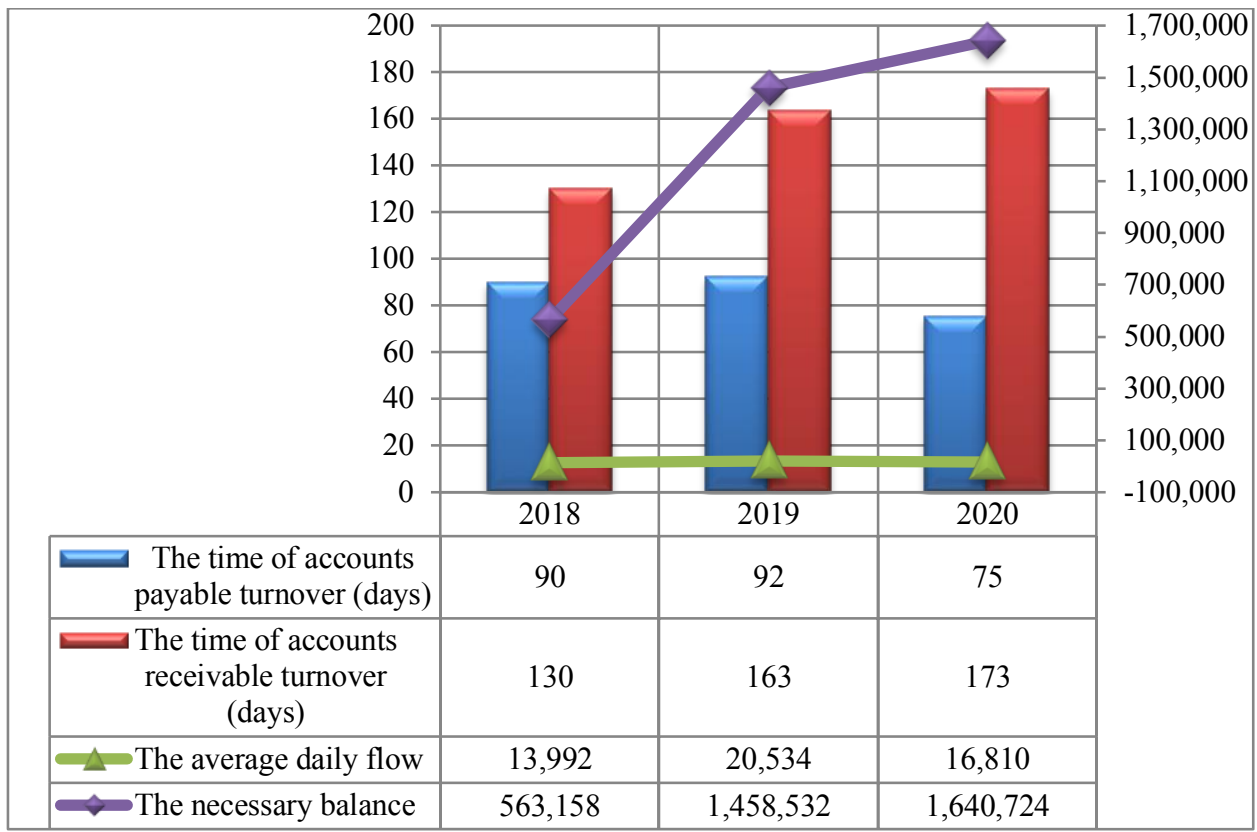

* The days of receivable and payable outstanding is calculated according to standard formulae, given on the basis of the data of the Balance-sheet and the statement of financial results.

* Calculating the necessary cash assets is done according to the formulae (5) and (6)

Fig. 2. Calculating the minimal cash assets.

Then the final stage of calculating the specific norm of absolute liquidity ratio follows.

The results of the previous calculations are used for that, as well as the items of the most urgent of the advance commitments from Section V of the Balance sheet. The results of calculation are presented in Fig.3.

\begin{tabular}{|c|c|c|c|c|}
\hline $2,500,000$ & & & & 1.000 \\
\hline $2,000,000$ & & & & 0.800 \\
\hline $1,500,000$ & & & & 0.600 \\
\hline $1,000,000$ & $\nabla$ & & & 0.400 \\
\hline 500,000 & & & & 0.200 \\
\hline 0 & 2018 & 2019 & 2020 & 0.000 \\
\hline $\begin{array}{c}\text { The necessary cash } \\
\text { balance }\end{array}$ & 563,158 & $1,458,532$ & $1,640,724$ & \\
\hline$\longrightarrow \mathrm{P} 1$ & $1,443,759$ & $2,024,715$ & $1,505,456$ & \\
\hline$\longrightarrow \mathrm{P} 2$ & 112,563 & 13,001 & 403,802 & \\
\hline$\Rightarrow R a b l$ (normal) & 0.362 & 0.716 & 0.859 & \\
\hline
\end{tabular}

* P1 - accounts payable; P2 - short-term debt assets and other short-term obligations.

Fig. 3. Calculating the specific norm of absolute liquidity ratio of the firm. 


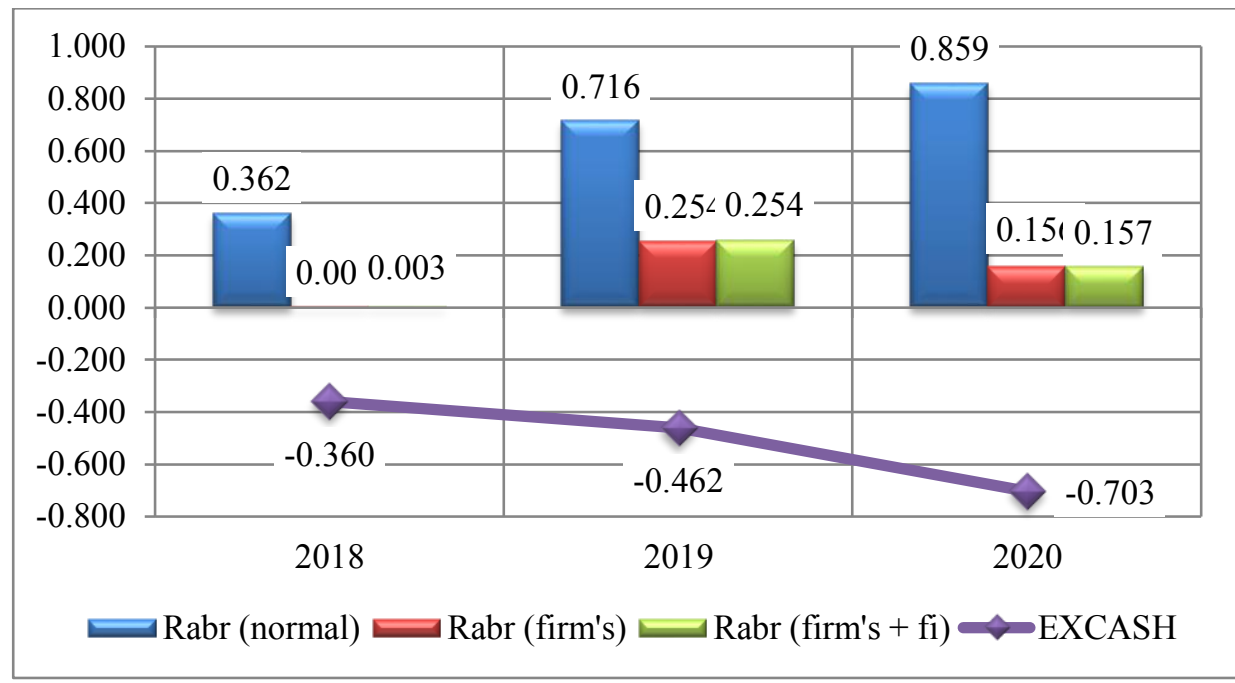

* Rabr (firm's + fi) - the absolute liquidity ratio calculated taking into account short-term financial investments

Fig. 4. Calculating the surplus of funds.

\section{Discussion}

Evidently the "standardized" absolute liquidity ratio supposes paying of short-term obligations only from absolutely liquid funds, so it shows surplus of those absolutely liquid funds, which is not true to the fact. The reason of it is that the standard way of calculating absolute liquidity ratio does not take into account the current operating mode of the firm, $i$. e. such important parts of operating activity as the average daily flow and the minimal daily spare money for financing continuous day-to-day running are not considered at all. Also the standard formula does not take into account any cash gaps which influence the paying capacity of the firm and which make the firm redirect the flow of money to financing the current operating activity, so that the debt load is growing. Thus the idea of financing the operating activity of the firm gets distorted, which could lead to wrong managerial decisions.

As is clearly seen, actually the firm does not have any surplus of funds. More than that, the firm operates in conditions of money stringency which is constantly growing, according to Pic. 4. In the calculation in question the numerator included only money assets; still even considering here short-term money investments is going to change the results not more than by the thousandths.

Thus the firm has money stringency, and the management of the firm stops the stringency using other sources. It explains the reasons of increasing the long-term debt load (according to the Balance sheet) for the sake of stopping the cash gap. The operating activities of the firm are not able to allow it generate the flow of money which is sufficient to meet its obligations.

\section{Conclusion}

The analysis of paying capacity of a firm is an important part of financial research of a firm. This analysis is important not only to the internal users (such as the management of the firm), but also to external ones. 
The paper offers and tries out the way of assessing the paying capacity of a firm on the basis of the criteria which demonstrate its individual specific operating mode. The paper presents that using only "standardized" ratios at assessing the paying capacity could lead to wrong, more than that, to just the opposite treatment of the calculation results. Here the ability of a firm (as a portfolio of assets) to generate the money flow by its operating activity is taken into account.

Doubtlessly if the management of a firm tries to accept the payment discipline, it will try to stop the cash gaps by using other sources of financing, sch as the debt capital. Still these decisions can finally aggravate the situation and to increase financial and operational risks.

\section{References}

1. L.Yu. Zimina, V.M. Perfilyeva, Paying capacity and liquidity as elements of financial state of a firm 12(64) (2018) https://cyberleninka.ru/article/n/platezhesposobnost-ilikvidnost-kak-elementy-analiza-finansovogo-sostoyaniya-predpriyatiya

2. O.G. Kovalenko, A.A. Kurilova, KNZh 4(17) https://cyberleninka.ru/article/n/metodika-otsenki-platezhesposobnosti-predpriyatiya-1

3. Liquidity. Calculating liquidity ratios. Bukhgalterskiy uchot. Nalogi. Audit, https://www.audit-it.ru/finanaliz/terms/liquidity/calculation_of_liquidity.html

4. A. Mottaeva, A. Ivashchenko, A. Ryattel, E3S Web of Conferences 164, 10038 (2020) https://doi.org/10.1051/e3sconf /202016410038

5. A.V. Bataev, A.A. Gorovoy, A.B. Mottaeva, Proceedings of the 32nd International Business Information Management Association Conference, IBIMA 2018 - Vision 2020: Sustainable Economic Development and Application of Innovation Management from Regional expansion to Global Growth, 102-114 (2018)

6. N.P. Suptelo. Vestnik Moskovskogo universiteta im. S.Yu. Vitte. Seriya 1: Ekonomika i upravleniye 1(32), 55-62 (2020) doi: 10.21777/2587-554X-2020-1-55-62

7. N.V. Chumakova, N.V. Yakovleva, O.V. Butkova, Kontsept 11 (2020) https://cyberleninka.ru/article/n/platezhesposobnost-i-likvidnost-teoreticheskiy-aspekt 